\title{
PEMBUKTIAN DALAM TINDAK PIDANA LALU LINTAS
}

\author{
Muh. Amiruddin \\ Universitas Islam Negeri (UIN) Alauddin Makassar \\ Email: Udinktabrani@yahoo.co.id
}

\begin{abstract}
Height mount accident of traffic ( lakalantas) alone if from lack of awareness of society in this case driver of motor vehicle with various coherent factor at $x$ 'self for example in the case of fitness of bodily, readiness of bouncing at the (time) of tired driver, influence of liquor, and forbidden. Condition of driver open big opportunity the happening of hard accident beside endanger safety of consumer of other roadway of Moo, sleepy, less skillful, fatigue, do not keep distance, accelerate untimely [is] example [of] mistake of driver in general.
\end{abstract}

Keyword : Accident, Traffic, Liquor

\begin{abstract}
Abstrak
Tingginya tingkat kecelakaan lalu lintas (lakalantas) sendiri jika dari kurangnya kesadaran masyarakat dalam hal ini pengemudi kendaraan bermotor dengan berbagai faktor yang melekat pada dirinya misalnya dalam hal kebugaran jasmani, kesiapan mental pada saat pengemudi kelelahan, pengaruh minuman keras, dan obat-obatan terlarang. Kondisi ketidaksiapan pengemudi membuka peluang besar terjadinya kecelakaan yang parah disamping membahayakan keselamatan pengguna jalan raya lainnya Lengah, mengantuk, kurang terampil, lelah, tidak menjaga jarak, melaju terlalu cepat adalah contoh kesalahan pengemudi pada umumnya.
\end{abstract}

Kata Kunci : Kecelakaan, Lalu Lintas, Minuman Keras 


\section{PENDAHULUAN}

emenjak manusia dilahirkan, manusia telah bergaul dengan manusia lainnya dalam wadah yang kita kenal sebagai masyarakat. Mula-mula ia berhubungan dengan orang tuanya dan setelah usianya meningkat dewasa ia hidup bermasyarakat, dalam masyarakat tersebut manusia saling berhubungan dengan manusia lainnya. Sehingga menimbulkan kesadaran pada diri manusia bahwa kehidupan dalam masyarakat berpedoman pada suatu aturan yang oleh sebagian oleh warga masyarakat tersebut ditaati. Hubungan antara manusia dengan manusia dan masyarakat diatur oleh serangkaian nilai-nilai dan kaidahkaidah.

Di dalam pembagian hukum konvensional, hukum pidana termasuk bidang hukum publik. Artinya hukum pidana mengatur hubungan antara warga negara dengan negara dan menitik beratkan kepada kepentingan umum atau kepentingan publik. Secara historis hubungan hukum yang ada pada awalnya adalah hubungan pribadi atau hubungan privat, tetapi dalam perjalanan waktu terdapat hal-hal yang diambil alih oleh kelompok atau suku dan akhirnya setelah berdirinya negara diambil oleh negara dan dijadikan kepentingan umum. Bukti yang jelas dapat kita lihat dalam Kitab Undang- Undang Hukum Pidana (KUHP) Pasal 344 barang siapa yang merampas nyawa orang lain atas permintaan orang itu sendiri yang jelas dinyatakan dengan kesungguhan hati diancam dengan pidana penjara paling lama dua belas tahun. ${ }^{1}$ Hak penuntutan terhadap perbuatan yang dilarang dan diancam hukuman terletak pada alat perlengkapan negara, yaitu jaksa penuntut umum. ${ }^{2}$

Eksistensi Indonesia sebagai negara hukum secara tegas disebutkan dalam Penjelasan Undang-Undang Dasar Negara Kesatuan Republik Indonesia 1945 (selanjutnya disingkat UUD NKRI 1945) setelah amandemen yaitu Pasal 1 ayat (3); "Indonesia ialah negara yang berdasar atas hukum (rechtsstaat)". Indikasi bahwa Indonesia menganut konsepsi welfare state terdapat pada kewajiban pemerintah untuk mewujudkan tujuan negara, sebagaimana yang termuat dalam alinea keempat Pembukaan UUD NKRI 1945, yaitu: "Melindungi segenap bangsa Indonesia dan seluruh tumpah darah Indonesia, memajukan kesejahteraan umum, mencerdaskan kehidupan bangsa, dan melaksanakan ketertiban dunia".Tujuantujuan ini diupayakan perwujudannya melalui pembangunan yang dilakukan

${ }^{1}$ Kumpulan Kitab Undang-Undang Hukum, KUH Perdata, KUHP dan KUHAP (Wipres:2008), h. 507.

${ }^{2}$ Teguh, Prasetyo, Hukum Pidana (Jakarta: Rajawali Pers,2012), h. 1. 
secara bertahap dan berkesinambungan dalam program jangka pendek, menengah, dan panjang. Pembangunan yang dilaksanakan Indonesia adalah pembangunan di segala bidang yang merupakan suatu bagian dari proses moderenisasi untuk menciptakan kesejahteraan dan ketentraman bagi masyarakat Indonesia. Pembangunan yang ada sekarang ini tentu saja memiliki kelebihan dan kekurangan dan salah satu kekurangan yang paling sering kita temui adalah tingginya tingkat kemacetan pada jam-jam sibuk. Kemacetan merupakan salah satu dampak negatif dari semakin majunya pembangunan terkhusus di bidang produksi kendaraan bermotor yang pada gilirannya menyebabkan semakin simpang siurnya lalu lintas jalan raya, hal ini disebabkan tidak berbandingnya jumlah kendaraan dan jumlah jalan yang pada akhirnya para pengguna jalan raya akan semakin tidak nyaman. Ketidaknyamanan pengguna jalan raya dalam aktivitasnya mendatangkan dampak yang sangat besar yaitu semakin tingginya beban psikologis, sehingga dapat menyebabkan stress yang berkepanjangan dan pada akhirnya menimbulkan kelalaian maupun kealpaan dalam melaksanakan kewajibannya sebagai pengguna jalan raya yang tentu saja dapat merugikan bagi dirinya dan orang lain.

Kelalaian atau kealpaan sendiri dapat dihindari dengan tetap memegang teguh dan patuh pada ketentuan hukum, hal ini didasari bahwa Indonesia adalah Negara Hukum yang mana para warga negaranya tunduk dan patuh pada aturanaturan yang berlaku.Hukum dan fungsinya mengatur seluruh aspek kehidupan berbangsa dan bernegara dapat memberikan konstribusi secara maksimal kepada pelaksanaan jika aparat penegak hukum dan seluruh lapisan masyarakat tunduk dan taat terhadap norma hukum. Dalam peristiwa kecelakaan lalu lintas (lakalantas) haruslah dipisahkan antara pelanggaran dan kejahatan. Karena untuk melakukan penuntutan didepan hukum maka kejadian yang terjadi haruslah merupakan kejahatan, sementara pada kecelakaan lalu lintas kejahatan yang terjadi merupakan kejahatan yang tidak disengaja atau dikarenakan oleh tindakan kelalaian atau kealpaan.

\section{PEMBAHASAN}

Pasal 310 ayat (4) UU RI No. 22 tahun 2009 tentang Lalu Lintas dan Angkutan Jalan yang unsur-unsurnya adalah sebagai berikut:

1. Setiap orang;

2. Mengemudikan kendaraan bermotor karena kelalaiannya;

3. Mengakibatkan orang lain meninggal dunia;

Ketentuan Pasal 310 ayat (4) UU RI No.22 Tahun 2009 tersebut dapat ditafsirkan yaitu sebagai berikut: 
Ad. 1. Yang dimaksud dengan"setiap orang "adalah orang perorangan atau korporasi pendukung hak dan kewajiban yang dalam suatu perkara tindak pidana lalu lintas, terdakwa dalam keadaan sehat jasmani dan rohani, sehingga terdakwa dapat mempertanggung jawabkan perbuatannya, dengan demikian Majelis Hakim berkeyakinan bahwa unsur "setiap orang" terbukti secara sah dan meyakinkan;

Ad.2. Menurut Undang-undang RI No.22 tahun 2009 tentang Lalu lintas dan Angkutan Jalan yang dimaksud dengan pengemudi adalah orang yang mengemudikan kendaraan bermotor dijalan raya, sedangkan kendaraan bermotor adalah setiap kendaraan yang digerakkan oleh peralatan mekanik berupa mesin selain kendaraan yang berjalan diatas rel kereta api. Hakim dalam memutuskan kasus tindak pidana lalu lintas harus memperhatikan kondisi terdakwa, misalnya apakah terdakwa telah mengetahui bahwa rem kendaraan yang dikemudikan oleh terdakwa berfungsi dengan baik, yang merupakan bentuk kelalaian dari seseorang pengemudi yang seharusnya selalu berhatihati dan selalu memperhatikan kondisi jalan raya, dengan demikian Majelis Hakim berkeyakinan bahwa unsur "Mengemudikan kendaraan bermotor yang karena kelalainnya mengakibatkan kecelakaan lalu lintas" terbukti secara sah dan meyakinkan;

Ad. 3. Akibat dari kecelakaan dapat diuraikan pada suatu fakta hukum, dengan demikian Majelis Hakim berkeyakinan bahwa unsur "mengakibatkan orang lain meninggal dunia" terbukti secara sah dan meyakinkan;

Semua unsur dari pasal 310 ayat (4) UU RI No.22 tahun 2009 tentang Lalu Lintas dan Angkutan Jalan haruslah dibuktikan secara sah dan meyakinkan untuk menjerat pelaku tindak pidana lalu lintas, disamping hal-hal yang dapat menghapuskan pertanggungjawaban pidana, baik sebagai alasan pembenaran dan atau alasan pemaaf.

Untuk menjatuhkan pidana terhadap pelaku tindak pidana, maka perlu dipertimbangkan terlebih dahulu keadaan yang memberatkan dan yang meringankan Terdakwa;

Keadaan yang memberatkan:

- Akibat perbuatan terdakwa ada orang lain yang kehilangan nyawa;

Keadaan Yang meringankan;

- Terdakwa berlaku sopan di pengadilan

- Terdakwa menyesali perbuatannya serta berjanji tidak mengulanginya; 
Hakim dalam pemeriksaan perkara pidana berusaha mencari kebenaran materil berdasarkan fakta-fakta yang terungkap dalam persidangan, serta berpegang teguh pada apa yang dirumuskan dalam surat dakwaan penuntut umum, sesuai dengan ketentuan baik hukum pidana formil maupun pidana materil dan syarat yang dapat dipidana seorang terdakwa, hal ini didasarkan pada pemeriksaan persidangan, dimana alat bukti yang diajukan Jaksa penuntut Umum, termasuk di dalamnya keterangan saksi yang saling bersesuaian ditambah keterangan terdakwa yang mengakui secara jujur perbuatan yang dilakukannya. Sebelum menetapkan atau menjatuhkan putusan terhadap pelaku tindak pidana yang dilakukan. Hakim terlebih dulu mempertimbangkan banyak hal. Seperti fakta-fakta pada persidangan, pertimbangan-pertimbangan yuridis dan non yuridis, keadaan dan latar belakang keluarga terdakwa, serta hal-hal lain yang terkait dalam tindak pidana yang dilakukan oleh terdakwa. Pertimbangan yuridis merupakan pembuktian dari unsur-unsur tindak pidana yang didakwakan jaksa penuntut umum, adapun unsur-unsur dalam Pasal 310 ayat (4) UU RI No. 22 tahun 2009 tentang Lalu Lintas dan Angkutan Jalan. Sesuai dengan apa yang yang didakwakan oleh jaksa penuntut umum serta harus didasarkan fakta persidangan. Hakim tidak boleh memutus suatu perkara dengan menjatuhkan hukuman lebih dari apa yang menjadi tuntutan Jaksa Penuntut Umum. Namun Hakim mempunyai kewenangan menjatuhkan hukum lebih rendah dari tuntutan dengan mempertimbangkan psikologi terdakwa selama persidangan, yakni terdakwa mengakui segala perbuatannya didepan persidangan serta alasan yang memberatkan dan meringankan juga menjadi dasar pertimbangan hakim sebelum menjatuhkan vonis terhadap terdakwa.

Pemidanaan merupakan suatu proses. Sebelum proses ini berjalan peran Hakim sangat penting. Ia mengkonkretkan sanksi pidana yang terdapat dalam suatu peraturan dengan menjatuhkan pidana bagi terdakwa. Jadi pidana yang dijatuhkan diharapkan dapat bmenyelesaikan konflik atau pertentangan dan juga mendatangkan rasa damai dalam masyarakat. Pemidanaan tidak dimaksudkan untuk menderitakan dan tidak diperkenangkan merendahkan martabat manusia, tapi merupakan pemberiaan makna kepada sistem hukum Indonesia. Meskipun pidana itu pada hakikatnya merupakan suatu nestapa. Namun, pemidanaan tidak maksudkan untuk menderitakan dan tidak di perkenangkan merendahkan martabat manusia.

Hakim sebelum memutuskan suatu perkara memperhatikan dakwaan jaksa penunut, keterangan saksi yang hadir dalam persidangan, keterangan terdakwa, alat bukti, syarat subjektif dan syarat objektif seseorang dapat dipidana, serta halhal yang meringankan dan memberatkan. Tindakan yang dilakukan oleh seorang 
terdakwa oleh Hakim harus dibuktikan dengan mengkaji unsur-unsur dari pasal tersebut kemudian disesuaikan dengan fakta-fakta yang terungkap dipersidangan serta alat bukti dengan menganalisanya. Dengan memperhatikan unsur-unsur yang terdapat dalam rumusan Pasal 310 ayat (4) UU RI No.22 tahun 2009 yaitu karena perbuatannya mengakibatkan hilangnya nyawa orang lain. Dalam mempertimbangkan apakah terdakwa melakukan tindak pidana atau tidak, dengan menganalisa unsur - unsur yang termuat dalam ketentuan Pasal 310 ayat (4) UU RI No. 22 tahun 2009 berdasarkan teori hukum dan doktrin lalu menghubungkannya dengan perbuatan terdakwa dengan peristiwa tersebut.

Pada pembuktian unsur-unsur yang terdapat dalam dakwaan yang didukung dengan terpenuhinya syarat mutlak dari pembuktian yaitu unus testis nullum testis yakni adanya minimal dua alat bukti maka terhadap unsur-unsur yang dimaksudkan di dalam dakwaan telah terpenuhi sepenuhnya, dimana untuk membuktikan dakwaannya Penuntut Umum dapat mengajukan alat bukti berupa keterangan saksi, alat bukti petunjuk dan keterangan terdakwa.

Setelah Majelis Hakim berkeyakinan bahwa terdakwa telah melakukan tindak pidana kelalaian yang menyebabkan meninggalnya orang lain maka Majelis Hakim juga harus mempertimbangkan apakah terhadap diri terdakwa ada alasan yang dapat menjadi dasar untuk menghapuskan pidana baik alasan pemaaf dan alasan pembenar. Adapun pertimbangan hukum oleh hakim dalam memutuskan perkara tentang kelalaian yang menyebabkan meninggalnya orang lain. Dalam memutus perkara, hakim sebaiknya mempertimbangkan bagaimana suasana pada saat kejadian apakah murni kejadian tersebut adalah kelalaian atau kesengajaan, bagaimana tingkat akibat yang ditimbulkan dari tindak pidana yang dilakukan serta bagaimana status terdakwa apakah dengan ditahannya terdakwa banyak dirugikan ataukah banyak yang terbengkalai terkhusus untuk kepentingan umum.

Hal ini dapat menjadi pertimbangan oleh hakim dalam memutuskan suatu perkara untuk meringankan pidana yang akan dijalani oleh terdakwa dengan memberikan pidana penjara selama 1 (tahun) 4 (empat) bulan. Karena terhadap terdakwa harus dinyatakan dapat mempertanggung jawabkan perbuatannya, untuk itu maka Majelis Hakim dalam menjatuhkan hukuman terdakwa terlebih dahulu juga mempertimbangkan mengenai hal-hal memberatkan serta hal-hal yang meringankan bagi diri terdakwa serta alasan-alasan yang sekiranya dapat membebaskan terdakwa dari tahanan. 


\section{PENUTUP}

Pasal 310 ayat (4) Undang- undang RI No.22 Tahun 2009 tentang Lalu Lintas dan Angkutan Jalan dan kedua pasal 359 KUHP yang dibuktikan dalam persidangan sudah saling mencocoki antara perbuatan dan unsur-unsur pasal. Menurut hemat penulis penerapan hukum materil dalam kasus tersebut sudah sesuai dengan hukum pidana yang berlaku di Indonesia. Seorang Hakim untuk menjatuhkan atau tidak menjatuhkan pidana terhadap pelaku yang dihadapkan dimuka persidangan, selain itu, juga harus mempunyai pengetahuan atau ilmu tentang hukum dengan baik, bukan hanya hukum secara formil, melaikan juga hukum secara materil agar tidak salah dalam menentukan mana perbuatan yang sesuai dengan unsur yang didakwakan. 


\section{DAFTAR PUSTAKA}

Ali, Mahsur. Dasar-Dasar Hukum Pidana. Jakarta: Sinar Grafika. 2015

Ansyori, Alik Alamsyah. Rekayasa Lalu Lintas Edisi Revisi. Malang: UMM Press. 2008

Ariman, Rasyid \& Raghib, Fahmi. Hukum Pidana. Malang. Setara Press. 2016s

Chazawi, Adam. Pelajaran Hukum Pidana: Stelsel Pidana, Tindak Pidana, TeoriTeori Pemidanaan \& Batas Berlakunya Hukum Pidana. Jakarta: PT RajaGrafindo Persada. 2002

Djamali Abdoel. Pengantar Hukum Indonesia Jakarta: Raja Grafindo Persada, 2005

Gunadi, Isnu ,Efendi Jonaedi, Hukum Pidana, Jakarta: Fajar Interpratama Mandiri 2014

Hamzah, Andi, Asas-asas Hukum Pidana, Jakarta: Rienika Cipta, 2008.

Lamintang, P.A.F. Dasar-Dasar Hukum Pidana Indonesia. Bandung: PT. Citra Aditya Bakti, 1997

Mahmud, Peter Marzuki. Penelitian Hukum Edisi Revisi. Jakarta: Kencana. 2015

Maramis, Frans. Hukum Pidana Umum dan Tertulis di Indonesia. Jakarta: PT Rajawali Pers. 2013

Marpaung, Leden. Putusan Bebas Masalah dan Pemecahannya. Jakarta: Sinar Grafika. 1995

Marpung, Leden. Asas-asas Praktikum Hukum Pidana, Jakarta: Sinar Grafika, 2005.

Maghdalena, Todingrara. Terhadap Pelanggaran Lalu Lintas Yang Menimbulkan Kecelakaan Berakibat Kematian Skripsi 2013, h. 21.

R. Soesilo, Kitab Undang-undang Hukum Pidana, Politeia: Bogor 